\title{
The nurses' work process in different countries: an integrative review
}

\author{
Processo de trabalho da enfermeira em diferentes países: uma revisão integrativa \\ Proceso de trabajo de la enfermera en diferentes países: una revisión integradora
}

\section{Juliana Alves Leite Leal', Cristina Maria Meira de Melo'}

' Universidade Federal da Bahia, School of Nursing, Postgraduate Program in Nursing. Salvador, Bahia, Brazil.

How to cite this article:

Leal JAL, Melo CMM. The nurses' work process in different countries: an integrative review. Rev Bras Enferm [Internet]. 2018;71(2):413-23. DOI: http://dx.doi.org/10.1590/0034-7167-2016-0468

Submission: 10-26-2016 Approval: 04-05-2017

\section{ABSTRACT}

Objective: To analyze the characteristics of nurses' work process in different countries. Method: We have used the integrative review method and selected 84 publications (articles, theses and dissertations) in national and foreign thesis banks and databases. We analyzed the evidence based on dialectical materialism. Results: The rejection of managerial tasks hides the singularity of nurses' work, due to the failure to understand the inseparable nature of managerial and healthcare tasks, given that it is what provides the expertise to coordinate the nursing work process and guide the healthcare work processes. The social and technical division is present in the work process in all countries studied, albeit in different ways. The nurse's position in the healthcare work process is subordinated to that of the physician. Conclusion: The characteristics are similar. The rejection of the dual nature of the work by nurses themselves due to alienation results in the non-recognition of their own work.

Descriptors: Nurses; Nursing; Work; Capitalism; Role of the Nurse.

\section{RESUMO}

Objetivo: Analisar características do processo de trabalho da enfermeira em diferentes países. Método: Utilizamos o método da revisão integrativa e selecionamos 84 publicações (artigos, teses e dissertações) em bases de dados e banco de teses nacionais e internacionais. As evidências foram analisadas na perspectiva do materialismo dialético. Resultados: A negação do trabalho gerencial esconde a singularidade do trabalho da enfermeira, pela não compreensão da natureza indissociável gerencial-assistencial, visto que isso confere a expertise para coordenar o processo de trabalho em enfermagem e direcionar os processos de trabalho em saúde. A divisão técnica e social está presente no processo de trabalho em todos os países estudados, ainda que sob formas distintas. O lugar da enfermeira no processo de trabalho assistencial é subordinado ao médico. Conclusão: As características são semelhantes. A negação da própria natureza dual do trabalho pela enfermeira, via alienação, culmina no não reconhecimento do próprio trabalho. Descritores: Enfermeiras; Enfermagem; Trabalho; Capitalismo; Papel do Enfermeiro.

\section{RESUMEN}

Objetivo: Analizar características del proceso de trabajo de la enfermera en diferentes países. Método: Utilizamos el método de la revisión integradora y seleccionamos 84 publicaciones (artículos, tesis y disertaciones) en bases de datos y banco de tesis nacionales e internacionales. Las evidencias fueron analizadas en la perspectiva del materialismo dialéctico. Resultados: La negación del trabajo gerencial esconde la singularidad del trabajo de la enfermera, por la no comprensión de la naturaleza indisociable gerencial-asistencial, visto que eso confiere la experiencia para coordinar el proceso de trabajo en enfermería y direccionar los procesos de trabajo en salud. La división técnica y social está presente en el proceso de trabajo en todos los países estudiados, aunque bajo formas distintas. El lugar de la enfermera en el proceso de trabajo asistencial está subordinado al médico. Conclusión: Las características son semejantes. La negación de la propia naturaleza dual del trabajo por la enfermera, vía alienación, culmina en el no reconocimiento del propio trabajo. Descriptores: Enfermeras; Enfermería; Trabajo; Capitalismo; Papel del Enfermero. 


\section{INTRODUCTION}

The work process is an intentional and conscious process in which workers, with their actions, promote, regulate and control their exchange with nature to obtain a planned result. It comprises three elements: the activity that is suitable to an end (work); the matter to which the work is applied (object of the work); the means and instruments that make the work easier $^{(1)}$.

As the work in healthcare is a collective effort, this sector's professionals have a certain degree of technical autonomy and, simultaneously, should strive to render health services through specialized tasks, established by the social and technical division of the work. As a result, we state that the work in the health sector is organized based on an increasing technical division, carried out by different workers and articulated through hierarchy.

Since the XIX century, when it was institutionalized as a working sector in the public sphere, Nursing has been divided into different types of worker: the nurse and the lady nurse, representing the separation between handwork and intellectual work.

Nursing is characterized as the field in the health sector responsible for the professional care of human beings ${ }^{(2)}$. Although healthcare is not exclusive to nurses, their work bears singularities in relation to that of other health professionals.

In this article, we defined the nurses' work process as the inseparable manner how they carry out healthcare and managerial tasks mediated by power relations, articulating philosophical, political and technical knowledge. In this process, nurses comply with health organization regulations, while meeting the anatomo-physiological and extra-biological needs of the users, the coordination demands of the nursing work process and the managerial demands of the healthcare work process, in a specific time in History and in a specific society ${ }^{(2)}$.

As a result, we believe the nurses' work process differs from that of other professionals in the sector due to the singularity of the former's position in healthcare, as the only ones to coordinate the nursing work process while guiding the healthcare work process, in addition to performing healthcare tasks. Our objective in this article was to analyze the characteristics of nurses' work process in different countries.

\section{METHOD}

In order to gather and systematize research results regarding nurses' work process, we applied the integrative review method. In this context, the integrative review includes the analysis of relevant research papers that enable the synthesis of several studies published and allows for general conclusions regarding a specific area of study ${ }^{(3)}$.

Initially, we defined two questions for our research. First: What are the characteristics that identify the nurses' work process, regardless of context, work space, time and country? And second: What are the common features of the work process of nurses in Brazil and in other countries?

Based on these questions, we defined the criteria for choosing the countries where the material reviewed came from: countries in distinct continents; with different proportion of nurse per inhabitant; and in different positions in the international ranking of scientific production, both in general terms and in nursing, according to data from the Organisation for Economic Co-operation and Development and SCImago Journal \& Country Rank. As a result, the countries selected were: Australia, South Africa, Brazil, Canada, Chile, China, the United States, Japan, Mexico, Portugal, the United Kingdom (England, Northern Ireland, Scotland and Wales) and Thailand.

Subsequently, we searched the literature in the selected databases combining the terms nurse and work process and nursing and work process, in addition to establishing the criteria for inclusion and exclusion of studies. Thus, we included full publications from research developed in the countries selected, available in the following databases: National Center for Biotechnology Formation (PUBMED), Scientific Electronic Library Online (SCIELO), Latin American and Caribbean Center on Health Sciences Information (BIREME), Comprehensive Medline (MEDLINE), Literature in the Health Sciences in Latin America and the Caribbean (LILACS), WEB OF SClENCE and SCOPUS. We also included publications found in Thesis Banks in Brazil and abroad (CAPES Portal, ETHESES, Brazilian Digital Library of Theses and Dissertations (BDTD), DART-Europe E-Theses, EThos, Theses Canada, Open Access Theses and Dissertations (OATD), Thèsesfr, Portuguese Open Access Scientific Repository (RCAAP), Chile Electronic Theses Portal, Web of Latin American Repositories and South African National ETD Portal).

After collecting the scientific publications in the data bases and thesis banks, we gathered 3,309 texts, from which we excluded 317 publications that were repeated in one or more bases, giving a total of 2,992 documents to which we applied the exclusion criteria, so that only studies related to work process and having nurses as subjects were selected.

Consequently, we analyzed the titles of the papers to identify those with a similar theme or those which, for not being comprehensive, were maintained for the next selection phase, and those which did not address the theme of nurse work. We excluded 936 publications.

The selection continued with the careful reading of the 2,056 abstracts of articles, theses and dissertations. Among them, there were papers whose focus diverged from the object defined, including articles about employee health, the nursing process, the systematization of nursing care and the history of the nursing sector. Other few studies referred to nursing assistants and technicians. As a result, we excluded 1,681 texts in this phase, leaving 375 publications for the last stage of the selection of empirical material.

Finally, we moved on to reading these 375 documents in full and excluding those which did not meet the same criteria applied to the abstracts. Therefore, we included in the study corpus 84 papers, 30 of which were articles and 54 theses and dissertations, which comprised the empirical material analyzed.

From these studies we extracted the information regarding the characteristics of nurses' work process and, subsequently, analyzed the evidence in the different countries, based on dialectical materialism. 
At first, the integrative review method led us to the search of scientific publications in the nursing sector that represented the construct of the nurses' work process, based on what had or not been said about this process in the different countries. Following historical materialism, we aimed not only at unveiling and analyzing the partiality of knowledge production in the nursing sector but, above all, exceeding the finite limits of this evidence to reflect on the perception of the whole, in addition to reflecting about what the authors, in their contradictory realities, revealed or disguised, brought light to or mystified.

\section{RESULTS}

In this article, we organized three of the evidences found and, based on them, we characterized part of the empirical material (27 publications).

Chart 1 - Characterization of part of the sample according to title, year, country, delineation, number of patients, interventions and outcomes, 2016

\begin{tabular}{|c|c|c|c|c|}
\hline Title & $\begin{array}{l}\text { Country } \\
\text { and year } \\
\text { of study }\end{array}$ & $\begin{array}{l}\text { Delineation } \\
\text { no. of patients }\end{array}$ & Interventions & Outcomes \\
\hline $\begin{array}{l}\text { The deskilling of registered } \\
\text { nurses: the social transformation } \\
\text { of nursing work in a New South } \\
\text { Wales hospital, 1970-1990(4) }\end{array}$ & $\begin{array}{l}\text { Australia } \\
1992\end{array}$ & $\begin{array}{l}\text { Ethnographic study } \\
\text { Locus - hospital }\end{array}$ & $\begin{array}{l}\text { Interview } \\
\text { Participant } \\
\text { observation }\end{array}$ & $\begin{array}{l}\text { Changes in nursing work; rhetoric of the } \\
\text { dominant groups does not reflect nurses' } \\
\text { work reality; precariousness }\end{array}$ \\
\hline $\begin{array}{l}\text { The process of nursing work in } \\
\text { hospitals }^{(5)}\end{array}$ & $\begin{array}{l}\text { Brazil } \\
2011\end{array}$ & $\begin{array}{l}\text { Qualitative research } \\
(\mathrm{N}=19) \\
\text { Locus - hospital }\end{array}$ & $\begin{array}{l}\text { Interview } \\
\text { Participant } \\
\text { observation }\end{array}$ & $\begin{array}{l}\text { Nurses' managerial tasks prevail over } \\
\text { healthcare ones; regarding healthcare - } \\
\text { procedures of greater technical complexity }\end{array}$ \\
\hline $\begin{array}{l}\text { Clinical governance and nursing } \\
- \text { a sociological analysis }{ }^{(6)}\end{array}$ & $\begin{array}{l}\text { United } \\
\text { Kingdom } \\
2007\end{array}$ & $\begin{array}{l}\text { Ethnographic study } \\
\text { Locus - hospital }\end{array}$ & $\begin{array}{l}\text { Field } \\
\text { observation/ } \\
\text { document } \\
\text { analysis/ } \\
\text { interview }\end{array}$ & $\begin{array}{l}\text { The confusing history of nursing as a } \\
\text { profession; subordination to physicians; } \\
\text { managerial tasks considered bureaucratic }\end{array}$ \\
\hline $\begin{array}{l}\text { Nurse management work process } \\
\text { analysis in a private hospital in } \\
\text { São Paulo: possibilities for care } \\
\text { management }{ }^{(7)}\end{array}$ & $\begin{array}{l}\text { Brazil } \\
2006\end{array}$ & $\begin{array}{l}\text { Qualitative study } \\
(\mathrm{N}=10) \\
\text { Locus- hospital }\end{array}$ & Interviews & $\begin{array}{l}\text { Execution of managerial tasks to increase } \\
\text { quality of care provided and streamline } \\
\text { costs; nurses mediate interactions between } \\
\text { employees; marked technical division }\end{array}$ \\
\hline $\begin{array}{l}\text { Constituting Modern Matron: } \\
\text { exploring role, identity and action } \\
\text { in an English NHS trust }{ }^{(8)}\end{array}$ & $\begin{array}{l}\text { United } \\
\text { Kingdom } \\
2011\end{array}$ & $\begin{array}{l}\text { Ethnographic study/ } \\
\text { multi-methods } \\
(\mathrm{N}=16) \\
\text { Locus - Health } \\
\text { system }\end{array}$ & $\begin{array}{l}\text { Interview } \\
\text { Observation } \\
\text { Document } \\
\text { analysis }\end{array}$ & $\begin{array}{l}\text { The contradictions and tensions between the } \\
\text { healthcare and managerial natures are reflected } \\
\text { in the data from modern matrons; Indefinition } \\
\text { of the object of intervention in the work }\end{array}$ \\
\hline $\begin{array}{l}\text { Performances of nurses in the } \\
\text { Family Health Strategy - building } \\
\text { competence in the work process }^{(9)}\end{array}$ & $\begin{array}{l}\text { Brazil } \\
2011\end{array}$ & $\begin{array}{l}\text { Qualitative research } \\
(\mathrm{N}=4) \\
\text { Locus - Primary } \\
\text { health care }\end{array}$ & $\begin{array}{l}\text { Participant } \\
\text { observation } \\
\text { Interviews } \\
\text { Workshops }\end{array}$ & $\begin{array}{l}\text { Nurses carry out healthcare and managerial } \\
\text { tasks; complexity of nurses' attitudes: } \\
\text { coordination of processes, supervision, } \\
\text { organization and planning. }\end{array}$ \\
\hline $\begin{array}{l}\text { Factors impacting staff nurse care } \\
\text { coordination }^{(10)}\end{array}$ & $\begin{array}{l}\text { United } \\
\text { States } \\
2010\end{array}$ & $\begin{array}{l}\text { Descriptive/ } \\
\text { quantitative study }\end{array}$ & Questionnaire & $\begin{array}{l}\text { Examines relationships between the nurse } \\
\text { practice environment, patient and } \\
\text { hospital characteristics; nurses coordinate } \\
\text { nursing work process; care coordination is a } \\
\text { key process to nurses. }\end{array}$ \\
\hline $\begin{array}{l}\text { Singularities of management work } \\
\text { in an accredited hospital(11) }\end{array}$ & $\begin{array}{l}\text { Brazil } \\
2012\end{array}$ & $\begin{array}{l}\text { Qualitative research } \\
(\mathrm{N}=12) \\
\text { Locus - hospital }\end{array}$ & Interview & $\begin{array}{l}\text { Contributions of nurses' managerial tasks } \\
\text { to hospital accreditation process; place of } \\
\text { articulation and duties of the organization }\end{array}$ \\
\hline $\begin{array}{l}\text { Ideal typical comprehension of } \\
\text { professional nursing practice at } \\
\text { public hospitals }{ }^{(12)}\end{array}$ & $\begin{array}{l}\text { Mexico } \\
2004\end{array}$ & $\begin{array}{l}\text { Phenomenological } \\
\text { study } \\
(\mathrm{N}=14) \\
\text { Locus - hospital }\end{array}$ & Interview & $\begin{array}{l}\text { The work of nurses is complex in nature; } \\
\text { social aspects and paradigms interfere in the } \\
\text { nurses' work process }\end{array}$ \\
\hline $\begin{array}{l}\text { The work of registered nurses } \\
\text { and care assistants with older } \\
\text { people in nursing homes: can the } \\
\text { outcomes be distinguished? }{ }^{(13)}\end{array}$ & $\begin{array}{l}\text { United } \\
\text { Kingdom } \\
2006\end{array}$ & $\begin{array}{l}\text { Hermeneutics/ } \\
\text { Multi-methods } \\
(\mathrm{N}=52) \\
\text { Locus - hospital }\end{array}$ & $\begin{array}{l}\text { Observation } \\
\text { Interview } \\
\text { Document } \\
\text { analysis }\end{array}$ & $\begin{array}{l}\text { Nurses are responsible for managing the } \\
\text { organizations; recognition of healthcare } \\
\text { tasks; shows the technical division in nursing } \\
\text { work }\end{array}$ \\
\hline
\end{tabular}

To be continued 
Chart 1

\begin{tabular}{|c|c|c|c|c|}
\hline Title & $\begin{array}{l}\text { Country } \\
\text { and year } \\
\text { of study }\end{array}$ & $\begin{array}{l}\text { Delineation } \\
\text { no. of patients }\end{array}$ & Interventions & Outcomes \\
\hline $\begin{array}{l}\text { The development of a nursing } \\
\text { technology: making visible } \\
\text { the nursing contribution to } \\
\text { development of critical care }{ }^{(14)}\end{array}$ & $\begin{array}{l}\text { United } \\
\text { Kingdom } \\
2006\end{array}$ & $\begin{array}{l}\text { Ethnographic study } \\
\text { Social representation } \\
(\mathrm{N}=12) \\
\text { Locus - hospital }\end{array}$ & $\begin{array}{l}\text { Interview } \\
\text { Observation } \\
\quad \text { Field } \\
\text { observation }\end{array}$ & $\begin{array}{l}\text { Low social recognition, despite performing } \\
\text { the duties of a physician; social and technical } \\
\text { division of work }\end{array}$ \\
\hline $\begin{array}{l}\text { Status morality and the politics of } \\
\text { transformation: an ethnographic } \\
\text { account of nurses in KwaZulu- } \\
\text { Natal, South Africa }^{(15)}\end{array}$ & $\begin{array}{l}\text { South } \\
\text { Africa } \\
2009\end{array}$ & $\begin{array}{l}\text { Historical - } \\
\text { ethnographic study } \\
\text { Locus - hospital }\end{array}$ & $\begin{array}{c}\text { Observation } \\
\text { Representations }\end{array}$ & $\begin{array}{l}\text { Reshaping nurses' status and professionalism } \\
\text { within a broader social and political context } \\
\text { post-apartheid }\end{array}$ \\
\hline $\begin{array}{l}\text { The identity work of leadership } \\
\text { in a professionalized context: the } \\
\text { case of nursing }\end{array}$ & $\begin{array}{l}\text { United } \\
\text { Kingdom } \\
2012\end{array}$ & $\begin{array}{l}(\mathrm{N}=32) \\
\text { Case Study } \\
\text { Locus - Health } \\
\text { system }\end{array}$ & $\begin{array}{l}\text { Interview } \\
\text { Participant } \\
\text { observation }\end{array}$ & $\begin{array}{l}\text { Nurses with an ideal position in the context } \\
\text { of organizations; ideologies and social } \\
\text { stereotypes are at odds with the position of } \\
\text { articulator of organizations. }\end{array}$ \\
\hline $\begin{array}{l}\text { The nature and use of knowledge } \\
\text { by district nurses in decision making } \\
\text { relating to first assessment visits }\end{array}$ & $\begin{array}{l}\text { United } \\
\text { Kingdom } \\
2000\end{array}$ & Qualitative study & $\begin{array}{l}\text { Interview } \\
\text { Observation }\end{array}$ & $\begin{array}{l}\text { Recognition of the healthcare nature of } \\
\text { nurses' work; rejection of the managerial } \\
\text { nature and leadership in the organizations }\end{array}$ \\
\hline $\begin{array}{l}\text { The relationship between staff } \\
\text { nurse perception of nurse } \\
\text { manager leadership behavior } \\
\text { and staff nurse job satisfaction in } \\
\text { a hospital applying for magnet } \\
\text { recognition status }{ }^{(18)}\end{array}$ & $\begin{array}{l}\text { United } \\
\text { States } \\
2011\end{array}$ & $\begin{array}{l}\text { Quantitative study } \\
(\mathrm{N}=500 \text { Staff } \\
\text { Nurses) } \\
(\mathrm{N}=15 \text { Managers/ } \\
\text { Nurses) }\end{array}$ & $\begin{array}{l}\text { Questionnaire } \\
\text { Multifactor } \\
\text { Leadership } \\
\text { Questionnaire } \\
5 X \text { Short } \\
\text { (MLQ) and the } \\
\text { Abridged Job } \\
\text { Descriptive } \\
\text { Index/Abridged } \\
\text { Job in General } \\
\text { (aJDI/aJIG) }\end{array}$ & $\begin{array}{l}\text { Leadership behavior related to the nature of } \\
\text { managerial work }\end{array}$ \\
\hline $\begin{array}{l}\text { Caring on: how nurses find } \\
\text { meaning in their work }{ }^{(19)}\end{array}$ & $\begin{array}{l}\text { Canada } \\
2000\end{array}$ & $\begin{array}{l}\text { Qualitative } \\
(\mathrm{N}=10) \\
\text { Locus - hospital }\end{array}$ & $\begin{array}{l}\text { Interviews - } \\
\text { Nurses }\end{array}$ & $\begin{array}{l}\text { Nurse values and features that help provide } \\
\text { meaning to the work; profession influenced } \\
\text { by the social and political spheres }\end{array}$ \\
\hline $\begin{array}{l}\text { Nursing perspectives on } \\
\text { women, health and work in } \\
\text { the socio-cultural context of } \\
\text { poor communities in Northeast } \\
\text { Thailand }{ }^{(20)}\end{array}$ & $\begin{array}{l}\text { Thailand } \\
2001\end{array}$ & $\begin{array}{l}\text { Ethnographic study } \\
\text { Locus - community } \\
\text { /Primary health care }\end{array}$ & $\begin{array}{l}\text { Interviews } \\
(\mathrm{N}=102) \\
\text { Focus group } \\
(\mathrm{N}=102) \\
\text { Case study } \\
(\mathrm{N}=49)\end{array}$ & $\begin{array}{l}\text { Intervention between gender, poverty, work, } \\
\text { health and the contribution of nursing } \\
\text { services to women care in low-income } \\
\text { communities. }\end{array}$ \\
\hline $\begin{array}{l}\text { Articulating between } \\
\text { management and care dimensions } \\
\text { in the nursing work process }{ }^{(21)}\end{array}$ & $\begin{array}{l}\text { Brazil } \\
2009\end{array}$ & $\begin{array}{l}\text { Qualitative research } \\
(\mathrm{N}=10 \text { nurses }) \\
\text { Locus - hospital }\end{array}$ & Interviews & $\begin{array}{l}\text { Describes the managerial and healthcare } \\
\text { dimensions of nurses' work; shows the } \\
\text { dual nature of said work and how the two } \\
\text { dimensions are articulated }\end{array}$ \\
\hline $\begin{array}{l}\text { The nursing work process: the } \\
\text { separation between planning and } \\
\text { care delivery }\end{array}$ & $\begin{array}{l}\text { Brazil } \\
2002\end{array}$ & $\begin{array}{l}\text { Qualitative research } \\
(\mathrm{N}=3 \text { nurses) } \\
(\mathrm{N}=2 \text { physicians) } \\
(\mathrm{N}=3 \text { nursing } \\
\text { assistants) } \\
\text { Locus - hospital }\end{array}$ & Interviews & $\begin{array}{l}\text { Presents the rigid technical division } \\
\text { of nursing work; separation between } \\
\text { intellectual work and handwork }\end{array}$ \\
\hline $\begin{array}{l}\text { The concept of "management } \\
\text { of care" in Chilean law: } \\
\text { interpretation and scope }\end{array}$ & $\begin{array}{l}\text { Chile } \\
2010\end{array}$ & Theoretical study & $\begin{array}{l}\text { Document } \\
\text { analysis }\end{array}$ & $\begin{array}{l}\text { Definition of care management equivalent to } \\
\text { coordination of the work process; managerial } \\
\text { tasks exclusive to nurses }\end{array}$ \\
\hline $\begin{array}{l}\text { Nursing services classification: } \\
\text { proposal to ensure quality care in } \\
\text { times of nursing shortages }\end{array}$ & $\begin{array}{l}\text { Chile } \\
2009\end{array}$ & $\begin{array}{l}\text { Theoretical study } \\
\text { Locus - Health } \\
\text { system }\end{array}$ & $\begin{array}{l}\text { Historical } \\
\text { narrative }\end{array}$ & $\begin{array}{l}\text { Definition of the scope of nursing work; } \\
\text { social recognition of nurses' work }\end{array}$ \\
\hline $\begin{array}{l}\text { Academia and the social } \\
\text { division of nursing work in the } \\
\text { Government sector: sinking or } \\
\text { surpassing?(25) }\end{array}$ & $\begin{array}{l}\text { Brazil } \\
2007\end{array}$ & $\begin{array}{l}\text { Qualitative meta- } \\
\text { analysis }\end{array}$ & $\begin{array}{l}\text { Analysis of } \\
\text { three research } \\
\text { pieces related to } \\
\text { work division }\end{array}$ & $\begin{array}{l}\text { Shows the trends of social and technical } \\
\text { division in the work }\end{array}$ \\
\hline
\end{tabular}




\begin{tabular}{|c|c|c|c|c|}
\hline Title & $\begin{array}{l}\text { Country } \\
\text { and year } \\
\text { of study }\end{array}$ & $\begin{array}{l}\text { Delineation } \\
\text { no. of patients }\end{array}$ & Interventions & Outcomes \\
\hline $\begin{array}{l}\text { Nurses and the Collective Care } \\
\text { Practices Within the Family } \\
\text { Health Strategy }^{(26)}\end{array}$ & $\begin{array}{l}\text { Brazil } \\
2011\end{array}$ & $\begin{array}{l}\text { Qualitative research } \\
(\mathrm{N}=11 \text { nurses }) \\
\text { Locus- Primary } \\
\text { health care }\end{array}$ & Interviews & $\begin{array}{l}\text { Nurse practice in collective care initiatives; } \\
\text { nurses' role as organizers and evaluators of } \\
\text { collective health initiatives }\end{array}$ \\
\hline $\begin{array}{l}\text { Technological changes and their } \\
\text { impact on the work process in the } \\
\text { health sector }\end{array}$ & $\begin{array}{l}\text { Brazil } \\
2002\end{array}$ & Study & $\begin{array}{l}\text { Document } \\
\text { analysis }\end{array}$ & $\begin{array}{l}\text { Organization of the work in the health } \\
\text { sector; social and technical division of work } \\
\text { in the health sector }\end{array}$ \\
\hline $\begin{array}{l}\text { The nurse's perceptions on } \\
\text { administrative actions in their } \\
\text { work process }^{(28)}\end{array}$ & $\begin{array}{l}\text { Brazil } \\
2004\end{array}$ & $\begin{array}{l}\text { Qualitative research } \\
(\mathrm{N}=10) \\
\text { Locus - hospital }\end{array}$ & Interview & $\begin{array}{l}\text { Nurses carry out managerial duties for the } \\
\text { health organization to work; they exercise } \\
\text { control; management practice makes nurses } \\
\text { differ from other sector employees }\end{array}$ \\
\hline $\begin{array}{l}\text { The nursing work process in the } \\
\text { pediatric wing of public university } \\
\text { hospitals in Parana, Brazil(29) }\end{array}$ & $\begin{array}{l}\text { Brazil } \\
2009\end{array}$ & $\begin{array}{l}\text { Historical research } \\
(\mathrm{N}=9) \\
\text { Locus - hospital }\end{array}$ & $\begin{array}{l}\text { Interview } \\
\text { Participant } \\
\text { observation }\end{array}$ & $\begin{array}{l}\text { Nurses' healthcare practice is subordinated } \\
\text { to the physician; nurses are responsible for } \\
\text { care management }\end{array}$ \\
\hline $\begin{array}{l}\text { The case for clinical nurse } \\
\text { leaders: guiding nursing practice } \\
\text { into } 21 \text { st century }{ }^{(30)}\end{array}$ & $\begin{array}{l}\text { United } \\
\text { States } \\
2010\end{array}$ & Case study & & $\begin{array}{l}\text { Expertise in medical knowledge, hierarchy and } \\
\text { work division present in the formation of the } \\
\text { field of work; nurses are responsible for process } \\
\text { intersection and the liason between employees. }\end{array}$ \\
\hline
\end{tabular}

Evidence 1 - The inseparable nature of managerial and healthcare tasks in nurses' work

This evidence was corroborated by our discovery that nurses carry out managerial tasks in addition to healthcare tasks in all the countries analyzed. However, the managerial aspect of nurses' work is rejected by the authors in most of the countries, which results in the rejection of the inseparable nature of managerial and healthcare tasks in said work.

The healthcare activities in the nurses' work process are more readily recognized, as evidenced by the authors who believe that the managerial activities prevent nurses from providing healthcare services to patients, deemed the most important aspect of their work ${ }^{(4-8)}$.

In Brazil and the United Kingdom, nurses' managerial activities are considered derogatory and described as bureaucratic, with the term "bureaucratic" being applied with the same meaning used by common sense, rather than by how it is used in the theoretical field of management ${ }^{(5-6,8)}$.

Due to the nature of their work, nurses privately coordinate the nursing work process and guide the healthcare work process in all the countries analyzed $\mathrm{d}^{(8-10,21-22)}$.

Evidence 2 -The social and technical division is present in the nurses' work process in all countries, albeit in different ways

All the countries included in this study have different categories for nursing workers ${ }^{(12-13,25-26)}$. These categories include: in Brazil, nurses, nursing technicians and nursing assistants; in Chile, nurses and nursing assistants; in Canada, Registered Nurse (RN) and Care Assistant (CA); and, in the United States and South Africa, Certified Nurse Assistant (CNA), Licensed Practical Nurse (LPN) and Registered Nurse (RN).

The categories within this field of work have different levels of training and time of academic training, as well as different duties in the provision of healthcare services. All countries have nursing workers without higher education who have intermediate or preparatory training courses, which enable them to continue training to become nurses in higher education institutions. However, at work, they only assist nurses, to whom they are hierarchically subordinated.

In some countries, nurses perform specialized procedures by developing their expertise in certain areas and taking over part of the physicians' work or performing technical procedures previously exclusive to physicians. As an example, we quote: "... political and professional imperatives have resulted in the devolvement of junior doctors' tasks to nurses resulting in the extension and expansion of nursing roles or the creation of new roles" ${ }^{\prime 14)}$. Nurses performing specialized technical activities are constantly submitted to evaluation systems to ensure their technical skills in the area in question.

Another type of social and technical division of work was identified in South Africa ${ }^{(15)}$, with nursing workers being differentiated according to race. The nursing field in post-apartheid South Africa faces an increasingly disparity of wages and working conditions, as well as two contrasting images among the nurses. Black nurses have less value than white nurses within their profession, not occupying the same spaces or performing the same tasks of white nurses, who are considered the "African elite". The article selected from that country states that the development of the profession was characterized by the presence of a "respectable" group of nurses from the African elite and another "downgraded" group of black nurses.

Evidence 3 - The nurse's position is subordinated to that of the physician in the healthcare work process

In the majority of the papers analyzed, we have identified the belief that the nurse's position in the work process is close to the patient, providing healthcare services together with the 
healthcare staff, with authors using expressions such as: "in the front-line" and "at the bedside"(6,16-17,28-30).

In nine of the countries analyzed - South Africa, Brazil, Canada, Chile, the United States, Mexico, Portugal, the United Kingdom and Thailand - we have also identified that nurses occupy a position of subordination in relation to the physician ${ }^{(6,12,14-15,18-20,24)}$. From the texts, it is worth mentioning the following expression: "nurses are the eyes and ears of physicians"(14).

\section{DISCUSSION}

After reading the scientific literature on nursing and considering the different contexts, workplaces and countries, it becomes clear that, due to the inseparable nature of managerial and healthcare tasks in nurses' work, the purpose of their work process always follows that nature. While performing their duties in healthcare services - i.e. coordinating the work process of other nursing workers, guiding the work process of other healthcare workers to ensure healthcare services are provided, organizing the environment and performing technical care procedures nurses constantly take into consideration both the needs of the health organization and of the users of healthcare services.

The nature of their work enables nurses to articulate the nursing work process and the healthcare work process. As a result, nurses are considered as intermediary managers due to the position they occupy in the organization, between the employing organization and other categories of healthcare workers.

We have also identified in the literature that nurses are considered as a professional fundamental to the execution of healthcare policies and the processes of change in the macro and micro level of the healthcare system. One of the examples taken from the texts was the role of nurses across different management levels in the healthcare system of the United Kingdom $^{(8)}$, when the adoption of measures in work process organization based on the model of managerialism had the main purpose of controlling costs.

Another example, in Brazil, is the role of nurses in hospital accreditation processes. According to the authors, the nurses' participation is responsible for the successful outcome of this process and leads to excellent results for the companies ${ }^{(11)}$. In both examples, it is worth noting that the nurses' role in the achievement of said excellent results for the healthcare organization is due to the position of liaison they assume in order to meet the needs of the healthcare organizations.

As explained by Marx, when workers sell their labor to the capitalist class, they no longer have any rights over it or over the product of their labor. In the same sense, nurses work under the control of their employer and their work also tends to serve the employer's interests.

As a result, based on the position occupied by them in the healthcare work process, nurses retain this conflicting relation of being a salaried employee exploited by their workers/capitalists and occupying a position of "pseudo-antagonism" by controlling the labor of other nursing workers and healthcare workers, who are also salaried and exploited. Nevertheless, in the latter relation, nurses represent the employer without really belonging to that class, that is, without having control of the means of production. In their work, they organize and coordinate the labor of healthcare workers to ensure: production in healthcare, the proper use of financial resources and that the full potential of workers is used to maintain the accumulation of capital or execute policies that represent the interest of the market and the elite, while preserving the fetish of defending good healthcare services to users requiring attention to healthcare.

Evidence indicates that nurses coordinate the nursing work process and guide the healthcare work process in all the countries analyzed. However, only Chile's legislation grants these professionals exclusive authority to carry out what is referred to as "care management" activities ${ }^{(23-24)}$, related to the application of the professional criterion on planning, organization, motivation and control of complete and safe care services in order to ensure continued care and support the institution's strategic guidelines and policies.

Based on this evidence, we have verified that the rejection of the managerial aspect and overestimation of the healthcare aspect of this type of work are based on the ideological foundation of the nursing profession's formation, which was historically crystallized in the nursing field.

As a result of the depreciation of the managerial aspect of the nurses' work process, which is inseparably composed of healthcare-managerial tasks, these professionals mischaracterize the nature of their own work. Consequently, nurses do not recognize the nature of their work and do not acknowledge in a clear manner the object of their work process, and any claim arising from this context will not have an effect on what they do, given that the ideologized aspect of their work is healthcare.

The rejection of the managerial dimension of nurses' work is convenient, above all, to their employers, whether from the public or private sector, given that there is no claim for payment for this unpaid task, as the workers themselves do not recognize it.

The inseparable nature of managerial and health-care tasks in nurse work is the essence of its singularity. However, for ideological reasons, nurses identify healthcare functions as their main responsibility, as it is shown in their daily caregiving tasks.

Nevertheless, it is worth noting that in all countries studied, nurses share the healthcare tasks with other nursing workers or other healthcare workers. In this sense, healthcare tasks are not exclusive to nurses, unlike managerial tasks, which include coordinate, control, supervise and guide the work process flow in nursing and healthcare.

In the literature, it was possible to notice the predominance of fetishized thinking, supported by the ideology of patientfocused care, that the management activities prevent the nurse from fully performing the "nursing practice", "the care", as in nursing healthcare activities are more valued than management ones. In some cases, the latter are even classified as a deviation from the nurse's role.

Due to the emphasis on healthcare tasks and the rejection of the managerial dimension of nurses' work, the dominant groups will have in their hands a mass of salaried employees mostly comprised of women who have historically occupied private work spaces. Unconsciously, they take on the invisibility of their work's dual dimension, even when in public spaces of service production, assuming only the dimension 
to help the 'doctor in the provision of treatment, being characterized as nurse-doctor's assistant, as stated by Collière ${ }^{(32)}$.

By hiding the managerial facet of nurses' work, which ensures the smooth operation of health units and the continuity of healthcare while controlling costs for health organizations, the value of the nurses' work is reduced.

The rejection of nurses' managerial tasks by the healthcare ideology is ingrained in the conception of the profession, which values the healthcare tasks and the technical procedures, aiming at a closer proximity with scientific knowledge. The rejection of the managerial work hides the singularity of nurses' work, due to the failure to grasp the inseparable nature of this dual dimension, and this aspect is what provides the expertise for nurses to coordinate the nursing work process and guide the healthcare work process, acting as a intermediary manager in the healthcare production process.

Concealing that the managerial dimension is inseparable from the nurses' work also hides the fact that this work is at the service of the employers the maintenance of the hegemonic model of healthcare. Even if some authors consider nurses responsible for management, it is necessary to give the credit that is due to this position that is occupied exclusively by nurses in the healthcare work process and which may be considered, up to this moment, the singularity of their work.

Based on the second evidence, we analyzed that the social and technical division are present in the nursing field in all countries. No country excluded or replaced this form of organization of the work process, which shows how the fragmentation of tasks is useful and inherent to the capitalist mode of production, as it increases the sector's profitability.

For Marx, the social division of work has always existed in all societies. It is inherent to human work and takes place in economic, political and cultural tasks alike. In traditional societies, the social division of the work corresponded the division of roles by gender, giving way, later on, to division by activity.

Braverman $^{(33)}$ calls our attention to that fact that the social division of work divides society by occupations, each one appropriate to a certain production area; the intense fragmentation of work destroys occupations considered in this sense and renders the worker unable to follow any production process in its entirety. In capitalism, the social division of work is forced, in a chaotic and anarchic manner, by the market, whereas the division of work in the unit of production is imposed by planning and control. Still in capitalism, the products of the social division of work are traded as merchandise, while the results of the fragmented worker's operation are all owned by the same capital. While the social division of work subdivides society, the fragmentation of work subdivides men.

Marx shows that when the workforce is traded as merchandise it promotes the complete separation between the worker and the means of production, alienating men from the essence of their work. Thus, the social division of work and the division of work further alienation and destroy the relations between men and women, given that they do not have power over the production process and do not benefit from the product of their work.

The technical division of the work introduces the fractioning of a work process that was originally unified, giving rise to other fragmented processes ${ }^{(27)}$. As a result, in this division, we find tasks that are complementary and interdependent, between fragmented and specialized tasks.

In addition, the social division of nursing work in South Africa indicates that, as affirmed by Braverman ${ }^{(33)}$, this division maintains the reproduction of a class society in the profession, also revealing remainders of the apartheid system within the nursing field.

Melo ${ }^{(34)}$, in his first book about social division in nursing work, argued that the social division become specific and more acute in the capitalist mode of production; that the organization of health services reflected this dominant mode of production; and that there was an ever-growing tendency of social and technical division of work in the health sector demanded by the labor market.

We have confirmed these arguments with the evidence of our study, which prove that the social division is constantly increasing and has been taking different forms, depending on the contexts, spaces and time.

Within this same evidence regarding the social and technical division, our findings indicate that nurses carry out specialized technical procedures previously exclusively or traditionally attributed to physicians. Those performing said duties are many times referred to as nurses with advanced expertise ${ }^{(35)}$.

The texts indicate that the execution of these advanced practices by nurses help reduce expenses in health services, which is seen as a justification for such a tendency in different countries. As nurses assume tasks previously attributed to doctors, and because the value of their work is lower than the doctors', health service provision becomes cheaper, something that interests not only employers, but also every government, given the increasing maintenance costs of healthcare systems.

The tendency for cost reduction imposed to the health sector by modern capitalism was more prominent in countries with advanced capitalism, but it has been spread to all countries, encouraged by the World Health Organization. The argument of economic crisis, reverberating in public service financing, employment and provision of services, justifies the usage of labor from non-medical professionals to perform medical services. Thus, the reduction in health financing has been producing reformation in healthcare systems, stimulating the use of nurses' labor and other non-medical professions in more advanced functions, as it were ${ }^{(35)}$.

International organizations, such as the World Health Organization and the Organisation for Economic Co-operation and Development (OECD) disseminate that the many international experiences of nurses assuming advanced practices are successful, and show that the transferring of tasks can be done without negative effects for the quality of the services provided or to the users' safety ${ }^{(36)}$

Actually, these "tendencies" help reduce labor expenses in the health sector and aim at maintaining the mode of production and capital accumulation in the health industry ${ }^{(35,37)}$.

An addition to this is the fact that nurses, by assuming tasks previously undertaken by doctors, do not make the profession socially valued, because neither the appropriation of technology nor the super-specialization have granted nurses more social acknowledgment or even monetary gain for their work. 
It is necessary to consider that health services are also favorable areas for Capital appreciation. Thus, the social and technical division of work, the assumption by the nurse of tasks or activities primarily assigned to physicians, as well as other forms of labor exploitation by capitalism, such as the stretching and intensification of a nurse's duties, help increase capital accumulation in this sector.

Mainly in countries such as the USA, the United Kingdom and Canada, we could identify some typologies originated from the technical division of work inside the nurse profession: Nurse practitioner refers to professionals with a master's degree, capable of issuing prescriptions and acting in diverse areas of health, independently from doctors, while Clinical nurse specialist refers to those with a master's degree in any clinical area, acting in institutions or in their own office, either in the education of patients and other professionals of their area or managing some kind of service, for instance the healing of wounds.

In England, specifically concerning primary health care, nurses with different functions are called nurse practitioner, practice nurse, health visitor and district nurse ${ }^{(38)}$. In the United States, nurses act on four different clinical practices: Clinical nurse specialist, Nurse anesthetist, Nurse midwife and Nurse practitioner.

In countries where capitalism is advanced, the technical division of work is horizontal, more delimited and the duties are better defined. In countries where health care provision is deficient, especially concerning the lack of health professionals such as physicians, for instance in Brazil and Portugal, one notes that nurses are required to fill the gaps generated by the absence of a physician in certain services.

An example can be found in Portugal Health Insurance 2011/2016, which emphasized that "the low proportion of nurse/ doctor mainly indicates a problem of productivity and cost-benefit" and concludes that "there is room for transferring and delegating tasks, especially from doctors unto nurses". In a recent report about the reformation in the hospital sector, it is made explicit that the attribution of "new functions to nurses" avoids calling up doctors for tasks that do not require a level of specialization.

Allen $^{(39)}$ affirms that nurses tend to cross professional boundaries only in the absence of medical personnel. In her study, the author identified situations in which nurses performed the service of a doctor, in order to maintain continuity in patients' treatment, such as prescribing medication and providing non-prescribed infusions so that doctors could register them afterwards. However, whenever doctors were present, the institutional order was kept.

In today's world, with financial capitalism, restrictive social policies and, among them, the containment of public expenditures concerning health, the relations of production in health affairs is exposed to more intense forms of exploitation of labor, also requiring that salaried workers be flexible. These social and economic determinations which multiply across countries, regardless of the work environment, influence the nursing profession in the sense of maintaining itself and acquiring new ways for the social and technical division of work. Historically, the nursing field of work is marked by an intense social and technical division among its workers, with the nurse supervising the other mid-level categories. The tendency of nurses taking up the responsibilities and tasks previously assumed by other professionals indicates that, in a capitalist mode of production, the reconstitution and renovation of social and technical division in the health field are permanent.

As for the third evidence presented, this should be observed: due to the spreading of the ideological thought that nurses are assistance providers, for the authors of the analyzed material, the main place of nurses is beside the patients, and by assisting them they become part of the frontline in health services.

This thought is related to the historical construction of the nurse profession, constituted to perform an assisting practice tributary to medical practice, as an information agent who conveys to the physician the facts on the nature and evolution of a disease and as an agent of execution who makes sure that therapeutic prescriptions are followed, always regarding the doctor as a boss. This subaltern relationship ensured that the nurse did not change the therapeutic prescriptions without medical order ${ }^{(32)}$.

The nurse work has always been marked by the constant presence of medicine in its relationships. Since the institutionalization of modern hospitals - when they ceased to be managed mainly by the clergy and with the predomination of modern medicine along with scientific knowledge and its Cartesian conceptions - the physician became the health practitioner with the highest power. In this modern space, the nurse, as a worker under the capitalist mode of production, is made to forward the physician's work, watching and controlling patients, helping doctors within health organizations and assuring the recovery of sick people.

A thin line divides the responsibilities of a physician and a nurse in the hospital. Formally, diagnosis is a physician's responsibility. This is one of the reasons why a lower status is attributed to the nurse in the social and technical division of a hospital work: without diagnosis, there is no patient, and therefore no need for nursing intervention. However, in daily practice, the boundaries between the nurse's notes and the physician's diagnosis are almost impossible to notice ${ }^{(39)}$.

Physicians, being in charge of attracting and maintaining patients/clients to health organizations, especially because they are responsible for diagnoses and decisions on treatments to be followed, have their knowledge put into the service of the means of production owners, often as salaried employees. They do, however, secure a position of dependency between the employer and their patients and also their presence in a health organization.

In the nursing field, less qualified employees - those with less training - are the ones who spend more time assisting patients. Nurses who perform technical procedures in patients interact with them by assisting them, but this is not the predominant place they occupy, owing also to a profound technical division in the nursing area $^{(34)}$.

In spite of the fetishist view that nursing work is subject to medical work, it is the nurse who paradoxically articulates the different fields of medical practice.

Nurses also articulate the workers of health services and the individuals to which treatment is provided. Their work is characterized by vigilance and continuity, which require them to exert such activity. Besides performing their own work, they make it possible for other health practitioners to carry out what the organization expects. 
As an articulator in health work, they deal with conflicts related to the distribution of healthcare work and the coordination of the work process in nursing itself. They also occupy a place of articulation, subordination, substitution and transition.

Therefore, we can say that the nurses' place is that of articulators, since they guide the healthcare work process and coordinate the work of the nursing technicians and assistants. However, the hegemonic view is that the job of a nurse is a subordinate one, something still evidenced in publications.

Moreover, health organizations use nurses as cheap labor of substitutive nature, transferring to them the responsibilities of a physician. Furthermore, health organizations, and healthcare systems and policies, which are heavily justified by the costcontainment argument and hide the profit-increase argument, spread the idea that nurse work is efficient from a capitalist point of view, because they are easily adaptable to the changes in these environments. Thus, nurse work is also a transition one.

Nurses, whose work process is not only continuous but also marked by a managerial/healthcare nature, are always in contact with the other, whether the user of health care services, or health practitioners, and they take on the role of an intermediary manager. This, however, is not the place that scientific production in different countries highlights.

In an article from Australia, the author points out that what is revealed in the academic production of this area is not in accordance with the reality of a nurse's work. He affirms that the "rhetoric of the dominant groups in nursing" does not reflect the reality of nurses' practical experience; because the idealized image of a nurse blurs the struggles and conflicts that occur in this field ${ }^{(4)}$.

This discourse, that the nurses' work is masked and hides the conflict and divergence, conforms to Silva's reflection ${ }^{40)}$ in her studies of fetishism in Brazilian nursing. The author considers that definitions utilized in this field of work hide the historical characteristics of its institutionalization within capitalism, as it is a field historically determined, heterogeneous, composed by categories of socially differentiated workers. It is also contradictory and cut by the technical divisions of the work, intrinsically marked by asymmetries, discrimination and conflict, not to mention the discourse that one category dominates the other.

We consider that the place of nurses, and the visibility of their work as service providers to individuals and communities, to health organizations and healthcare systems still needs more profound analysis, so as promote discussions concerning their social representativeness, thus revealing the concrete reality of the profession, overcoming the ideologized and fetishized image of the nurse as the physicians' auxiliary, and as a professional focused on sickness rather than on health: such an image imposes a passivity as if nurses had no need of being seen as workers.

The place of the nurse in the working process is that of an intermediary manager who bridges the gap between nursing professionals and other health practitioners. The employer considers this to be the place of the nurse, and that from this place she is most able to coordinate work processes, guide the flow of health services and control the input and costs of organizations. However, the employer does not pay extra for that, and nurses do not claim any payment either for performing this task or for having such an expertise. Thus, the ideology remains that nurses are those who provide care, that their rightful place is at the sick person's bedside, and that sickness itself is the focus of their work. Such conceptions support and sustain the hegemony of the biomedical model, contribute to the subjection of the nurse to the physician and keep them doubly explored.

\section{Limitations of this study}

Some possible restricting aspects of this study are related to data collection. Firstly because of the large amount of texts identified in the selection process of empiric material. This was partly due to the fact that, while searching on databases and online thesis banks, we had to use combinations of broad descriptors such as nursing, even though the focus was actually on nurses, and the studies not always distinguished or delimited which category of nursing workers was included. Secondly, the DeCs has no registered descriptor which corresponds to the "work process" of health practitioners.

\section{Contributions to the health and Nursing field}

It has been highlighted that the evident similarity in the work process of nurses in countries from different continents, the singular nature this work inseparably combining healthcare and managerial tasks, and the reflection upon the contradictions that pervade nursing work are some of the contributions brought to this field of knowledge.

\section{FINAL CONSIDERATION}

The working process in the studied countries presents similarities on most characteristics, which shows that the nurses' work is similar in nature. However, we identified some distinct features, which are related to the historical conformation of this field of work in different countries and also to the geographic, economic and cultural context.

We theorized that the nurses' work would be under the influence of historical, economic, political and social variations in a macro way, not to mention the social and technical division of this work, the model in which work is organized and the model of assistance. Nevertheless, such differences as found in the countries did not alter the pattern of nurse work.

The mode of production, we sought to assure, does not act as an immediate cause of social phenomena, but it is a determining element, which is a condition of possibility in the set of relations within which all phenomena are inscribed. Furthermore, the crisis capitalism faces provokes changes in the organization of nurse work and in the health systems of different countries.

Finally, there are indeed differences related to the social and technical division of the nursing work, among nurses and also in regard to the organization of the healthcare work process. Thus, nurses take on the responsibility of other professions in certain countries, particularly in some where there is a shortage of medical professionals in healthcare systems. 


\section{REFERENCES}

1. Marx K. O capital: crítica da economia política. Livro I. São Paulo, SP: Boitempo; 2013.

2. Melo CMM, Santos TA, Leal JAL. Processo de trabalho assistencial-gerencial da enfermeira. In: PROENF Programa de Atualização em Enfermagem: Gestão: Ciclo 4. Porto Alegre: Artmed Panamericana; 2015. p. 45-75.

3. Mendes KDS, Silveira RCCP, Galvão CM. Revisão integrativa: método de pesquisa para a incorporação de evidências na saúde e na enfermagem. Texto Contexto Enferm[Internet]. 2008[cited 2013 Oct 10];17(4):758-764. Available from: http://dx.doi. org/10.1590/S0104-07072008000400018

4. Herdman E. The deskilling of registered nurses: the social transformation of nursing work in a New South Wales hospital, 1970-1990[Tese]. [Internet]. Austrália: University of Wollongong; 1992[cited 2014 Jan 20]. Available from: http://ro.uow.edu.au/theses/1729

5. Presotto GV. O processo de trabalho do enfermeiro no contexto hospitalar[Tese]. [Internet]. Universidade Federal do Triângulo Mineiro; 2011 [cited 2014 Jan 12]. Available from: http://www.uftm.edu.br/upload/ensino/enfermsaude/atencao_a_saude_ Giovanna_Valim_Presotto.pdf

6. Staniland KM. Clinical governance and nursing: a sociological analysis[Tese]. [Internet] University of Salford; 2007 [cited 2014 Mar 04]. Available from: http://usir.salford.ac.uk/2062/1/Thesis_2008_Final_May_2009.pdf

7. Hausman M. Análise do processo de trabalho gerencial do enfermeiro em um hospital privado no município de São Paulo: possibilidades para o gerenciamento do cuidado[Tese]. [Internet]. Universidade de São Paulo; 2006[cited 2014 Mar 01]. Available from: http://www.teses.usp.br/teses/disponiveis/7/7131/tde-03102006-102248/pt-br.php

8. Kiewicz LM. Constituting Modern Matron: exploring role, identity and action in an English NHS trust[Tese].[Internet]. Inglaterra: University of York; 2011 [cited 2014 Jun 15]. Available from: http://etheses.whiterose.ac.uk/id/eprint/1907

9. Kawata LS. Os desempenhos da enfermeira na Saúde da Família - a construção da competência no processo de trabalho[Tese]. [Internet]. Universidade de São Paulo; 2011[cited 2014 Mar 29]. Available from: http://www.teses.usp.br/teses/disponiveis/22/22133/ tde-30112011-083404/pt-br.php

10. Duva IH. Factors impacting staff nurse care coordination[Tese]. [Internet]. Emory University; 2010[cited 2014 Feb 18]. Available from: http://pid.emory.edu/ark:/25593/8kdsv

11. Oliveira AG. Singularidades do trabalho gerencial em um hospital acreditado[Tese]. [Internet]. Universidade Federal de Minas Gerais; 2012 [cited 2014 Mar 06]. Available from: http://hdl.handle.net/1843/GCPA-8UMGTG

12. Banda MMZ. Compreensão típico ideal da prática profissional do enfermeiro em hospitais públicos[Tese]. [Internet]. Universidade de São Paulo; 2004 [cited 2013 Dec 04]. Available from: http://www.teses.usp.br/teses/disponiveis/22/22132/tde-13102004150910/pt-br.php

13. Heath HBM. The work of registered nurses and care assistants with older people in nursing homes: can the outcomes be distinguished?[Tese]. [Internet]. Brunel University; 2006 [cited 2014 Jan 08]. Available from: http://europepmc.org/theses/ eth/488676

14. Crocker $\mathrm{C}$. The development of a nursing technology: making visible the nursing contribution to development of critical care[Tese]. [Internet]. UK: University of Nottingham; 2006 [cited 2014 Mar 04]. Available from: http://eprints.nottingham.ac.uk/11903/

15. Hull EA. Status morality and the politics of transformation: an ethnographic account of nurses in Kwa Zulu-Natal. [Tese]. [Internet]. London School of Economics and Political Science; 2009[cited 2014 Feb 09]. Available from: http://etheses.Ise.ac.uk/320/

16. Ogilvie C. The identity work of leadership in a professionalized context: the case of nursing. Inglaterra[Tese]. [Internet]. University of Warwick; 2012 [cited 2013 Dec 15]. Available from: http://wrap.warwick.ac.uk/id/eprint/53812

17. Kennedy CM. The nature and use of knowledge by district nurses in decision making relating to first assessment visits[Tese]. [Internet]. Queen Margaret University; 2000 [cited 2014 Mar 24]. Available from: http://etheses.qmu.ac.uk/id/eprint/169

18. Bormann LB. The relationship between staff nurse perception of nurse manager leadership behavior and staff nurse job satisfaction in a hospital applying for magnet recognition status[Tese]. [Internet]. University of Louisville; 2011[cited 2014 Feb 24]. Available from: http://dx.doi.org/10.18297/etd/129

19. Uhrynuk BG. Caring on: how nurses find meaning in their work[Internet]. Canadá: Royal Roads University; 2000 [cited 2013 Dec 09]. Available from: http://www.collectionscanada.ca/obj/s4/f2/dsk1/tape4/PQDD_0019/MQ49236.pdf

20. Jongudomkarn D. Nursing perspectives on women, health and work in the socio-cultural context of poor communities in Northeast Thailand[Tese]. [Internet]. UK: Robert Gordon University; 2001 [cited 2014 Mar 06]. Available from: http://hdl.handle. net/10059/603

21. Hausmann M, Peduzzi M. Articulação entre as dimensões gerencial e assistencial do processo de trabalho do enfermeiro. Texto Contexto Enferm [Internet]. 2009[cited 2014 Mar 06];18(2):258-65. Available from: http://www.scielo.br/pdf/tce/v18n2/08.pdf

22. Peduzzi M, Anselmi ML. O processo de trabalho de enfermagem: a cisão entre planejamento e execução do cuidado. Rev Bras Enferm [Internet]. 2002[cited 2013 Dec 09];55(4):392-8. Available from: http://www.scielo.br/pdf/reben/v55n4/v55n4a06.pdf 
23. Milos P, Bórquez B, Lorrain Al. La "Gestión del Cuidado" en la legislación chilena: interpretación y alcance. Cienc Enferm[Internet]. 2010 [cited 2014 Jan 26];16(1):17-29. Available from: http://dx.doi.org/10.4067/S0717-95532010000100003

24. Milos, P, Lorrain, Al, Simonetti M. Caracterización de servicios de enfermería. Propuesta para asegurar una atención de calidad en tiempos de escasez de enfermeras. Cienc Enferm[Internet]. 2009[cited 2014 Jan 26];15(1):17-24. Available from: http://dx.doi. org/10.4067/S0717-95532009000100003

25. Bujdoso YLV, Trapé CA, Pereira EG, Soares CB. A academia e a divisão social do trabalho na enfermagem no setor público: aprofundamento ou superação. Ciênc Saúde Colet [Internet]. 2007[cited 2014 Jan 26];12(5):1363-74. Available from: http://www. scielo.br/pdf/csc/v12n5/28.pdf

26. Fortuna CM, Matumoto S, Pereira MJB, Mishima SM, Kawata LS, Camargo-Borges C. O enfermeiro e as práticas de cuidados coletivos na estratégia saúde da família. Rev Latino-Am Enfermagem [Internet]. 2011[cited 2014 Jan 26];19(3):581-8. Available from: http://www.scielo.br/pdf/rlae/v19n3/pt_18.pdf

27. Peduzzi M. Mudanças tecnológicas e seu impacto no processo de trabalho em saúde. Trab Educ Saúde. 2002;1(1):75-91.

28. Vaghetti H, Reis D, Kerber NC, Azambuja E, Fernandes G. Percepções dos enfermeiros acerca das ações administrativas em seu processo de trabalho. Rev Bras Enferm[Internet]. 2004 [cited 2014 Aug 01];57(3):316-20. Available from: http://www.scielo.br/ pdf/reben/v57n3/a12v57n3.pdf

29. Yamamoto DM, Oliveira BRG, Vieira CS, Collet N. O processo de trabalho dos enfermeiros em unidades de alojamento conjunto pediátrico de instituições hospitalares públicas de ensino do Paraná. Texto Contexto Enferm [Internet]. 2009[cited 2014 Aug 01];18(2):224-32. Available from: http://www.scielo.br/pdf/tce/v18n2/04.pdf

30. O'Grady TP, Clarck JS, Wiggins MS. The case for clinical nurse leaders: guiding nursing practice into 21 st century. Nurse Leader[Internet]. 2010[cited 2013 Dec 15];8(1):37-41. Available from: http://dx.doi.org/10.1016/j.mnl.2009.11.002

31. Leal JAL. Processo de trabalho da enfermeira em diferentes países. [Tese]. Escola de Enfermagem da Universidade Federal da Bahia: Salvador; 2016.

32. Collière MF. Promover a vida. Lisboa: Lisboa, Porto, Coimbra: Lidel; 1999.

33. Braverman H. Trabalho e capital monopolista: a degradação do trabalho no século XX. Rio de Janeiro: Zahar; 1981.

34. Melo CMM. Divisão Social do Trabalho e Enfermagem. São Paulo: Cortez, 1986.

35. Buchan J, Temido M, Fronteira I, Lapão L, Dussault G. Enfermeiros em funções avançadas: uma análise da aceitação em Portugal. Rev Latino-Am Enfermagem[Internet]. 2013[cited 2016 Jan 20];21(spe):38-46. Available from: http://www.scielo.br/pdf/rlae/ v21nspe/pt_06.pdf

36. Delamaire ML, Lafortune G. Nurses in Advanced Roles: A Description and Evaluation of Experiences in 12 Developed Countries, OECD Health Working Paper No. 54[Internet] OECD Publishing: 2010 [cited 2016 Jan 20]. Available from: http://dx.doi. org/10.1787/5kmbrcfms5g7-en

37. Pires D, Gelbcke FL, Matos E. Organização do trabalho em enfermagem: implicações no fazer e viver dos trabalhadores de nível médio. Trab Educ Saúde. 2004;2(2):311-26.

38. Toso BRGO, Filippon J, Giovanella L. Atuação do enfermeiro na Atenção Primária no Serviço Nacional de Saúde da Inglaterra. Rev Bras Enferm[Internet]. 2016[cited 2016 Aug 11];69(1):182-191. Available from: http://dx.doi.org/10.1590/0034-7167.2016690124i

39. Allen D. The nursing-medical boundary: a negotiated order? Sociology of Health and Illness[Internet]. 1997 [cited 2016 Feb 19];19(4):498-520 Available from: http://onlinelibrary.wiley.com/doi/10.1111/j.1467-9566.1997.tb00415.x/abstract

40. Silva GB. Enfermagem Profissional: análise crítica. São Paulo: Cortez; 1986. 